\title{
A Comparative Study on Pedestrians' Intention to Violate Traffic Rules: The Case of China and Djibouti
}

\author{
Waiss Ali Aden ${ }^{a}$, Shengchuan Zhao ${ }^{a^{*}}$, Fazle Subhan ${ }^{b}$, Hongmei Zhou ${ }^{a}$, Irfan Ullah ${ }^{a}$ \\ aSchool of Transportation and Logistics, Dalian University of Technology, Dalian 116024, China \\ ${ }^{b}$ Faculty of Management \& Economics, Dalian University of Technology, Dalian 116024, China
}

\begin{tabular}{|c|c|}
\hline ARTICLE INFO & A B S T R A C T \\
\hline $\begin{array}{l}\text { DOI: } 10.31075 / \text { PIS.66.03.01 } \\
\text { Professional paper } \\
\text { Received: } 12.08 .2020 . \\
\text { Accepted: } 25.09 .2020 . \\
\text { Corresponding author: } \\
\text { szhao@dlut.edu.cn }\end{array}$ & \multirow{3}{*}{$\begin{array}{l}\text { Crashes involving pedestrians account for a higher proportion of all road traffic } \\
\text { crashes. So, in order to develop more effective safety measures, it is important to } \\
\text { determine the causes of the crashes that involve pedestrians. This paper adopts } \\
\text { an extended Theory of Planned Behavior (TPB) to predict and explain pedestrians' } \\
\text { intention to violate traffic rules when crossing the road. In addition to the three } \\
\text { traditional determinants of intention (instrumental attitude, Subjective norm and } \\
\text { perceived behavioral control), this paper analyzes the effects of sensation seeking } \\
\text { and conformity tendency on the intention to violate traffic rules while crossing the } \\
\text { road. In order to analyze the relationships among the aforementioned variables, a } \\
\text { survey was conducted in Dalian city (China) and Djibouti city (Djibouti), } 452 \\
\text { participants from Dalian city and } 828 \text { participants from Djibouti city were } \\
\text { interviewed. Structural Equation Modeling (SEM) was employed to analyze the } \\
\text { collected data. The results indicated that the instrumental attitude, the subjective } \\
\text { norm, and perceived behavioral control positively affected the behavioral intention } \\
\text { to violate traffic rules when crossing the road for both cities except for perceived } \\
\text { behavioral control which was not significant for Dalian city. Conformity tendency } \\
\text { and sensation seeking had a significant and positive impact on behavioral intention } \\
\text { for Djibouti city. However, for Dalian city, conformity tendency significantly and } \\
\text { positively affected the behavioral intention, but sensation seeking did not. Several } \\
\text { empirical and practical implications were also discussed. }\end{array}$} \\
\hline Keywords: & \\
\hline $\begin{array}{l}\text { Pedestrians' } \\
\text { Crossing behavior, } \\
\text { Theory of Planned Behavior, } \\
\text { Dalian city (China), } \\
\text { Djibouti city (Djibouti), } \\
\text { Traffic safety }\end{array}$ & \\
\hline
\end{tabular}

\section{Introduction}

Road traffic accident became one of the principal causes of deaths (World Health Organization,2013). Pedestrians having no protective equipment around them are more vulnerable to road traffic accidents than vehicle drivers and so account for a higher proportion of road traffic accidents (Ben-ari \& Shay, 2012; R. Zhou \& Horrey, 2010). In Djibouti, pedestrian fatalities are the leading category of road traffic fatalities, accounting for $60 \%$ of total deaths (World Health Organisation,2015). However pedestrian safety research in Djibouti has been quite rare due to the limitations of resources and institutional capacity in the area and this limitation is shared by other developing countries. In China, the way that pedestrians crossed the road can be different from other countries because $40 \%$ of the travel is accomplished on foot, accompanied by very common traffic violations (Yang, Deng, Wang, Li, \& Wang, 2006).
Nowadays, pedestrian injury for both countries (China and Djibouti) became a major public health problem among adults. Most of road traffic accidents involving pedestrians are caused by either the drivers' errors or violations but also the pedestrian violation of traffic rules (Qu et al., 2016). Among the factors that lead a pedestrian to violate the rules of the road traffic is the long waiting time, it means that the more road crossing waiting time is increasing, the more the pedestrians are willing to violate the road traffic rules in order to reach their destination as soon as possible to save time. They will use the traffic gap or will use mid-block to cross the road in a faster way (Xuehao Chu \& A., n.d.; Zhuang \& Wu, 2011) found that, concerning the crossing at unmarked roadways, $65.7 \%$ of pedestrians did not give attention to looking at the vehicles around them and try to cross anxiously the road. 
Many empirical studies explored the driver behavior in order to understand the driver error or violation (Tova Rosenbloom a, 2004) which are considered among the main factors causing road accidents, but only few studies explored pedestrian road crossing violation behavior. Therefore, to ensure a safer traffic environment for all road users especially pedestrians, a full understanding of psychological factors of pedestrians is necessary for exploring their intention towards road traffic rules violation during road crossing.

One of the most used models for predicting behavioral intention is the Theory of Planned Behavior (TPB), developed by (AJZEN, 1991). According to this theory, intention can be interpreted as individual's willingness to perform a given behavior (Martin Fishbein Icek Ajzen, 2010). The TPB assumes three independent constructs of intention which are attitude, subjective norm and perceived behavioral control (Martin Fishbein Icek Ajzen, 2010). The attitude construct towards behavior refers to an individual's positive or negative evaluation towards the behavior of interest. The subjective norm refers to the perceived social pressure to perform or not to perform the behavior in question and the perceived behavioral control construct refers to the perceived ease or difficulty of performing the behavior of interest and it is assumed to reflect past experience as well as anticipated impediments and obstacles (AJZEN, 1991).

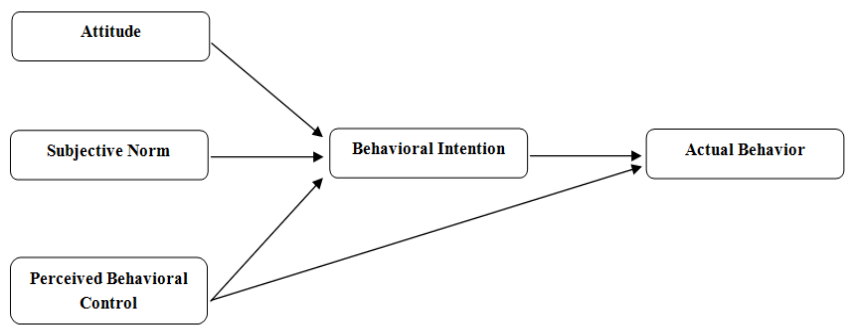

Figure 1. The theory of planned behavior adapted from (AJZEN, 1991)

To better understand the decision-making process of the people who violate traffic rules, some empirical studies have identified the TPB model as an adequate model [11-14] (Forward, 2018; Iversen, 2004; Traffic et al., 2013; R. Zhou, Horrey, et al., 2009). The TPB has been widely employed a lot to investigate drivers' behavior in many contexts such as speeding (Elliott et al., 2003), texting or using cell mobile phone while driving a car (Nemme \& White, 2010; R. Zhou, Wu, et al., 2009), driving and drinking (Moan \& Rise, 2011; Traffic et al., 2013) and wearing seat belt (Brijs et al., 2011). TPB has also been adopted to examine health related behaviors including eating, exercise, lifestyle, sexual health, drug and alcohol use, and hand hygiene (Ã \& Hausenblas, 2005; Ajzen, 2014; Albarracín, 2001; Boyle, n.d.; Fila \& Smith, 2006; Godin, 1996; Guo et al., 2007; Kingdom, 1999; L.Blue, 1995; Mcauley, 1993; Norman \& Conner, 2006; Rhodes \& Courneya, 2003; Rye, 1999; Vicki S. Conn \& Toni Tripp-Reimer, n.d.; Vm et al., 2016).
Based on the empirical studies just mentioned above, we noticed that the researchers' primary interest in the traffic environment was to focus on the driver behavior in the most part; therefore, pedestrian-focused studies are not as common as the driver-focused studies in the literature. Moreover, the existing literature on pedestrian behavior is mostly theoretical. However, in Africa and Asia, empirical studies on pedestrian behavior are little exploited compared to the driver behavior and need more attention because, according to the statistical data, two-thirds of road accident victims are pedestrians. In this study, we studied the pedestrian's behavior when crossing the road. Therefore, the first objective of this paper is to find out the most significant factors that determine pedestrians' intention to violate traffic rules when crossing the road by employing the TPB. The second objective is to deliver policies for the future implementation of some safety measures specific to pedestrians in order to protect them against the vehicle crashes in the context of developing countries.

The remainder of this paper is organized as follows. The next section provides a brief overview of TPB, which is a foundation for evaluating the determinants of pedestrians' intention to violate the road traffic rules. Section 3 presents the research method and data. Section 4 presents the results. Section 5 concludes this study with a discussion of the results and directions for future research.

\section{Theoretical background and research framework}

Theory of Planned Behavior was developed from the Theory of Reasoned Action (TRA) by (AJZEN, 1991) and has been validated in several studies. Drawing from those studies and the framework shown in Figure1, we hypothesize that:

H1: The Attitude has a positive effect on behavioral intention to violate traffic rules when crossing the road.

H2: The subjective norm positively influences the behavioral intention to violate traffic rules when crossing the road.

H3: The Perceived Behavioral intention has a positive effect on behavioral intention to violate traffic rules when crossing the road.

Among the personality trait an individual possesses is sensation seeking, which is defined as "the try to find of varied like intense sensations, complex ,novel, and experiences, and the readiness to take social, physical and financial risks for the sake of such new experiences"(Marvin Zuckerman, 1979). For evaluating sensation seeking, (Marvin Zuckerman, 1979)developed the Sensation Seeking Scale Form (SSS-V) which has been widely used. Sensation seekers were more likely to involve in thrill-seeking behavior(Zuckerman, 2015). Therefore, sensation seekers would be expected to engage in risky activities such as the violation of traffic rules. 
This relationship was also supported in previous studies (Marvin Zuckerman, 2006). Therefore, we propose:

H4: The Sensation Seeking positively influences the behavioral intention to violate traffic rules when crossing the road.

Finally, the conformity tendency referred a tendency to adjust behavior when an individual is around other persons so as to adapt the perceived expectation of the social conformity. People who exhibit conformity tendency would be expected to violate traffic rules when they see people do it. This relationship was also corroborated in previous research (Behavior, 1995; Khan et al., 1999; Santor et al., 2000; R. Zhou, Horrey, et al., 2009). Therefore, we hypothesize:

H5: The Conformity tendency has a positive effect on behavioral intention when crossing the road.

Figure 2 depicts the relationships hypothesized in this study.

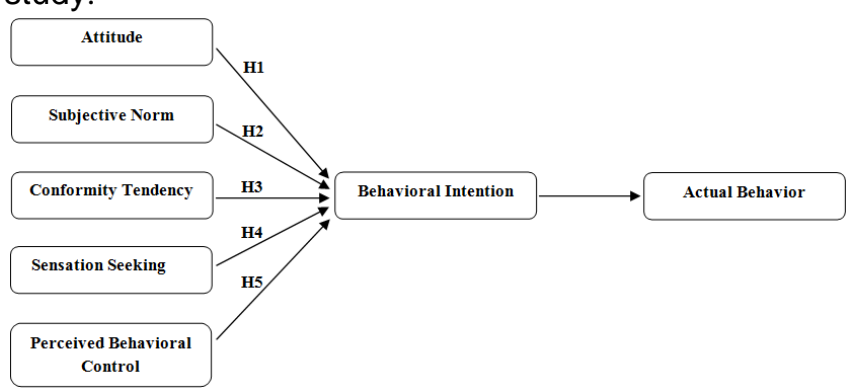

Figure 2. Research-modified theory of planned behavior model

\section{Research data and method}

\subsection{Study area}

This study was conducted in two cities which are Dalian city and Djibouti city. Dalian City is one of the largest cities in Liaoning province in Northeast China. Djibouti City is located in east Africa and is the capital city of the Republic of Djibouti. It has an area of $630 \mathrm{~km} 2$; it is populated in 2013 by around 570,000 inhabitants, more than $2 / 3$ of the country's total population. In Djibouti city, the study took place in the road section between national road number one and Hassan gouled road. The reason we selected this area is that, according to the Djibouti police, among the accidents that happened in this area in $2018,60 \%$ of the victims were pedestrians. The location which was selected during Dalian data collection was the areas located near the Northgate and Westgate of Dalian University of Technology. The survey content was divided into three parts. In the first part, we proposed the participants four risky road crossing behaviors and asked them if they had in the past crossed the road like one or more of the proposed crossing behaviors. These four risky situations were, "Crossing pedestrian crosswalks when the signal is red if no vehicle is visible", "Listening to music or talking on the phone while crossing", "Crossing the road in places where there is not a pedestrian crosswalk (i.e., jaywalking)", and "Crossing the pedestrian crosswalks when other pedestrians begin to cross even though the signal is red". The second part was a list of several questions which served as items for the latent variables used in this study. The respondent had to respond to the questions in part two based on their response to the question in part one. The last part of the survey consisted of recording the respondents' demographic characteristics such as gender, age, income (monthly), etc.

\subsection{Participants}

During the survey, participants were randomly selected in the study areas of the two cities and asked to report their previous behavior as well their attitudes towards violating traffic rules when crossing the road.

500 questionnaires were distributed during data collection in Dalian and 900 questionnaires in Djibouti city. After elimination of incomplete responses, 452 samples were obtained, indicating a response rate of $90.4 \%$ for Dalian data. For Djibouti city 828 valid samples were obtained, indicating a response rate of $92 \%$. All respondents gave their written consent to take part in the survey and provided some personal information. Tables 1 and 2 summarize the socioeconomic characteristics of the participants. About $54 \%$ of the 452 respondents were male, and $46 \%$ were female in Dalian city but in Djibouti city $60 \%$ of the 828 respondents were male, and $40 \%$ were female. The majority of the respondents in Dalian city were aged between 0 and 25 (80\%), followed by those aged between 26 and 45 years old (16\%) and for Djibouti city $51 \%$ were age between 0 and 25 year old ,followed by those aged between 26 and 45 years old (41\%). Regarding their monthly income, most of the participants in Dalian city had low income (82\%) with a salary less than or 3000 Yuan (438 USD), same for Djibouti city where the majority of the participants (81\%) received a low income which is less than or 70000 Djiboutian franc (394 USD). Concerning the last education level, $83 \%$ of participants from Dalian city have bachelor and master degree, followed by those who held a PhD degree (6\%). In Djibouti city, most of the participants $(86 \%)$ have a high school diploma and bachelor degree followed by those who hold a master's degree $(8 \%)$. all the participants who took part in this survey were citizens of these two countries(China and Djibouti).We separated the pedestrians into two groups according to their choice of the reckless behavior of crossing the road which are the Pedestrian violator and the Pedestrian non-violator, the majority of participants $(96 \%)$ from the Djibouti city are Pedestrian violators and admitted that they behave recklessly when crossing the road but On the other hand, $40 \%$ of the participants from the Dalian city are non-violating pedestrians. 
Table 1. Social demographic characteristics (Djibouti city)

\begin{tabular}{|c|c|c|c|c|}
\hline Attributes & Sub-group & $\begin{array}{c}\text { Frequen } \\
\text { cy }\end{array}$ & $\begin{array}{l}\text { Percenta } \\
\text { ge } \%\end{array}$ & $\underset{\%}{\text { Cumul }}$ \\
\hline Gender & $\begin{array}{l}\text { Male } \\
\text { Female }\end{array}$ & $\begin{array}{l}500 \\
328\end{array}$ & $\begin{array}{l}60 \% \\
40 \%\end{array}$ & $\begin{array}{c}60 \% \\
100 \%\end{array}$ \\
\hline Age group & $\begin{array}{c}0-25 \\
26-45 \\
46-65 \\
\text { More than } 66\end{array}$ & $\begin{array}{c}419 \\
340 \\
69 \\
0\end{array}$ & $\begin{array}{c}51 \% \\
41 \% \\
8 \% \\
0 \%\end{array}$ & $\begin{array}{l}51 \% \\
92 \% \\
100 \% \\
100 \%\end{array}$ \\
\hline $\begin{array}{c}\text { Education } \\
\text { level }\end{array}$ & $\begin{array}{c}\text { High school } \\
\text { diploma } \\
\text { Bachelor } \\
\text { degree } \\
\text { Master } \\
\text { degree } \\
\text { PhD degree } \\
\text { Other } \\
\text { diploma } \\
\end{array}$ & $\begin{array}{c}474 \\
240 \\
66 \\
0 \\
48\end{array}$ & $\begin{array}{c}57 \% \\
29 \% \\
8 \% \\
0 \% \\
6 \%\end{array}$ & $\begin{array}{c}57 \% \\
86 \% \\
94 \% \\
94 \% \\
100 \%\end{array}$ \\
\hline Occupation & $\begin{array}{c}\text { Student } \\
\text { Employee } \\
\text { Unemployed } \\
\text { Retired }\end{array}$ & $\begin{array}{c}333 \\
275 \\
212 \\
8\end{array}$ & $\begin{array}{c}40 \% \\
33 \% \\
26 \% \\
1 \%\end{array}$ & $\begin{array}{l}40 \% \\
73 \% \\
99 \% \\
100 \% \\
\end{array}$ \\
\hline $\begin{array}{c}\text { Monthly } \\
\text { income(Djibout } \\
\text { ian franc) }\end{array}$ & $\begin{array}{c}0-70000 \\
70001- \\
150000 \\
150001- \\
250000 \\
250001- \\
350000 \\
\text { More Than } \\
350001\end{array}$ & $\begin{array}{c}670 \\
141 \\
17 \\
0 \\
0\end{array}$ & $\begin{array}{l}81 \% \\
17 \% \\
2 \% \\
0 \% \\
0 \%\end{array}$ & $\begin{array}{c}81 \% \\
98 \% \\
100 \% \\
100 \% \\
100 \%\end{array}$ \\
\hline $\begin{array}{l}\text { Having driving } \\
\text { license }\end{array}$ & $\begin{array}{l}\text { Yes } \\
\text { No }\end{array}$ & $\begin{array}{l}182 \\
646\end{array}$ & $\begin{array}{l}22 \% \\
78 \%\end{array}$ & $\begin{array}{l}22 \% \\
100 \%\end{array}$ \\
\hline $\begin{array}{l}\text { Being a local } \\
\text { resident }\end{array}$ & $\begin{array}{l}\text { Yes } \\
\text { No }\end{array}$ & $\begin{array}{c}828 \\
0\end{array}$ & $\begin{array}{c}100 \% \\
0 \%\end{array}$ & $\begin{array}{l}100 \% \\
100 \%\end{array}$ \\
\hline $\begin{array}{l}\text { Pedestrian } \\
\text { group }\end{array}$ & $\begin{array}{c}\text { Violator } \\
\text { No-Violator }\end{array}$ & $\begin{array}{c}794 \\
34\end{array}$ & $\begin{array}{l}96 \% \\
4 \%\end{array}$ & $\begin{array}{l}96 \% \\
100 \%\end{array}$ \\
\hline
\end{tabular}

(Note: 1 Djiboutian franc $=0.0056$ USD)

\subsection{Measurement scales}

A careful review of the literature on pedestrian behavior has been done in order to select the adequate measurement items. All items of the present study were validated in previous studies (Reynolds et al., 2006; $\mathrm{H}$. Zhou et al., 2016; R. Zhou, Horrey, et al., 2009). The questionnaire was translated into Chinese language by two English professors and Road Traffic Safety experts. In order to check the wording and relevance of the selected items in the current study, we interviewed two college professors from the School of Transportation and Logistics at Dalian University of Technology. With the help of the aforementioned professors, 22 items were selected to conduct the pilot survey. The pilot survey was done in October 2019 in Dalian city and helped to further estimate the validity and wording of the selecting items. 50 participants (students) were interrogated and the outcome was used to improve the wording and remove the least relevant items. At the end of this process, all twenty two items remained for the final survey. All items were measured on a 5-point Likert scale ranging from "strongly disagree" to "strongly agree" and "neutral" as mid-point anchor. As suggested by (Studies, 1996), items measuring the same variable were assembled together. (Studies, 1996) showed that grouping items is more suitable for the respondents. A detailed list of the items is displayed in Table 3.

Table 2. Social demographic characteristics (Dalian city)

\begin{tabular}{|c|c|c|c|c|}
\hline Attributes & Sub-group & Frequency & $\begin{array}{c}\text { Percentage } \\
\%\end{array}$ & Cumul\% \\
\hline Gender & $\begin{array}{c}\text { Male } \\
\text { Female }\end{array}$ & $\begin{array}{l}245 \\
207 \\
\end{array}$ & $\begin{array}{l}54 \% \\
46 \% \\
\end{array}$ & $\begin{array}{c}54 \% \\
100 \% \\
\end{array}$ \\
\hline Age group & $\begin{array}{c}0-25 \\
26-45 \\
46-65 \\
\text { More than } \\
66\end{array}$ & $\begin{array}{c}364 \\
71 \\
17\end{array}$ & $\begin{array}{c}84 \% \\
16 \% \\
4 \%\end{array}$ & $\begin{array}{c}84 \% \\
96 \% \\
100 \%\end{array}$ \\
\hline $\begin{array}{c}\text { Education } \\
\text { level }\end{array}$ & $\begin{array}{c}\text { High school } \\
\text { diploma } \\
\text { Bachelor } \\
\text { degree } \\
\text { Master } \\
\text { degree } \\
\text { PhD degree } \\
\text { Other } \\
\text { diploma } \\
\end{array}$ & $\begin{array}{c}30 \\
181 \\
195 \\
25 \\
21 \\
0\end{array}$ & $\begin{array}{c}7 \% \\
40 \% \\
43 \% \\
6 \% \\
4 \% \\
0 \%\end{array}$ & $\begin{array}{c}7 \% \\
40 \% \\
90 \% \\
96 \% \\
100 \% \\
100 \%\end{array}$ \\
\hline Occupation & $\begin{array}{c}\text { Student } \\
\text { Employee } \\
\text { Unemployed } \\
\text { Retired }\end{array}$ & $\begin{array}{c}383 \\
51 \\
11 \\
7\end{array}$ & $\begin{array}{c}85 \% \\
11 \% \\
2 \% \\
2 \%\end{array}$ & $\begin{array}{c}85 \% \\
96 \% \\
98 \% \\
100 \%\end{array}$ \\
\hline $\begin{array}{l}\text { Monthly } \\
\text { income } \\
\text { (yuan) }\end{array}$ & $\begin{array}{c}0-3000 \\
3001-6000 \\
6001-10000 \\
10001- \\
15000 \\
\text { More Than } \\
15001 \\
\end{array}$ & $\begin{array}{c}372 \\
44 \\
22 \\
14 \\
0\end{array}$ & $\begin{array}{c}82 \% \\
10 \% \\
5 \% \\
3 \% \\
0 \%\end{array}$ & $\begin{array}{c}82 \% \\
92 \% \\
97 \% \\
100 \% \\
0 \%\end{array}$ \\
\hline $\begin{array}{l}\text { Having } \\
\text { driving } \\
\text { license } \\
\end{array}$ & $\begin{array}{l}\text { Yes } \\
\text { No }\end{array}$ & $\begin{array}{l}239 \\
213\end{array}$ & $\begin{array}{l}53 \% \\
47 \%\end{array}$ & $\begin{array}{c}53 \% \\
100 \%\end{array}$ \\
\hline $\begin{array}{c}\text { Being a } \\
\text { local } \\
\text { resident }\end{array}$ & $\begin{array}{l}\text { Yes } \\
\text { No }\end{array}$ & $\begin{array}{l}113 \\
339\end{array}$ & $\begin{array}{l}25 \% \\
75 \%\end{array}$ & $\begin{array}{l}25 \% \\
100 \%\end{array}$ \\
\hline $\begin{array}{l}\text { Pedestrian } \\
\text { group }\end{array}$ & $\begin{array}{c}\text { Violator } \\
\text { No-Violator }\end{array}$ & $\begin{array}{l}270 \\
182 \\
\end{array}$ & $\begin{array}{l}60 \% \\
40 \% \\
\end{array}$ & $\begin{array}{c}60 \% \\
100 \%\end{array}$ \\
\hline
\end{tabular}

(Note: 1 Yuan $=0.15$ USD)

\subsection{Data processing method}

The present study analyzed the determinants of Pedestrian Behavior intention about the non-complying of traffic rules for two countries which are China and Djibouti. In order to test the hypotheses about causal relationships between latent variables, the structural equation modeling (SEM) is the most common analysis technique and it examines the relationships between constructs, which are measured by several consistent items. The relationship between latent variables of the research model has been hypothesized in above section. As suggested by (Fornell et al., 1988), the model was tested using a two-step approach. 
So, in the first step, confirmatory factor analysis was conducted to test the reliability and validity of the latent variables (constructs). In the second step, SEM is used to measure the hypothesized relationships among the latent variables of the research model. The $\mathrm{R}$ program and lavaan package (Rosseel, 2011) were used during the analysis of the data.

Table 3.Latent Variables with theirs indicators

\begin{tabular}{|c|c|c|}
\hline constructs & items & wording \\
\hline Attitude & $\begin{array}{l}\text { Att1 } \\
\text { Att2 } \\
\text { Att3 } \\
\text { Att4 } \\
\text { Att5 } \\
\text { Att6 }\end{array}$ & $\begin{array}{l}\text { It is safe to cross the road during the red } \\
\text { light. } \\
\text { You will take any opportunity to cross the } \\
\text { road no matter the crossing types described } \\
\text { above. } \\
\text { Crossing the road like the crossing type that } \\
\text { you have selected in question } 1 \text {, will save } \\
\text { you a time as pedestrian. } \\
\text { Saving time is very important in a daily life. } \\
\text { Crossing the road like the crossing type that } \\
\text { you have selected in question } 1 \text {, will make } \\
\text { you feel more comfortable. } \\
\text { Comfort is very important in a daily life. }\end{array}$ \\
\hline $\begin{array}{l}\text { Subjective } \\
\text { Norm }\end{array}$ & $\begin{array}{l}\text { SN1 } \\
\text { SN2 } \\
\text { SN3 } \\
\text { SN4 }\end{array}$ & $\begin{array}{l}\text { Your family will accept that you cross the } \\
\text { road like the crossing type that you have } \\
\text { selected in question } 1 . \\
\text { You will accept that your family crosses the } \\
\text { road like the crossing types that you have } \\
\text { selected in question. } \\
\text { Your family wants you to involve in traffic } \\
\text { light violation. } \\
\text { Your family has always approved your } \\
\text { opinion even if it's bad. }\end{array}$ \\
\hline $\begin{array}{l}\text { Perceived } \\
\text { Behavioral } \\
\text { Control }\end{array}$ & $\begin{array}{l}\text { PBC1 } \\
\text { PBC2 } \\
\text { PBC3 } \\
\text { PBC4 }\end{array}$ & $\begin{array}{l}\text { You cross the road without paying attention } \\
\text { to traffic. } \\
\text { You have the ability to cross the road as } \\
\text { crossing type that you have selected in } \\
\text { question } 1 . \\
\text { You cross the road even though obstacles } \\
\text { (parked vehicles, buildings, trees, etc.) } \\
\text { obstruct the visibility. } \\
\text { You would endanger your life if you cross the } \\
\text { road as the crossing type that you have } \\
\text { selected in question } 1 \text {. }\end{array}$ \\
\hline $\begin{array}{l}\text { Behavioral } \\
\text { intention }\end{array}$ & $\begin{array}{l}\mathrm{B} 11 \\
\mathrm{BI} 2 \\
\mathrm{BI} 3\end{array}$ & $\begin{array}{l}\text { It is likely that you will attempt to cross the } \\
\text { street while the traffic light is red for } \\
\text { pedestrians. } \\
\text { You intend to engage in a pedestrian } \\
\text { violation. } \\
\text { You will probably involve in a pedestrian } \\
\text { violation behavior. }\end{array}$ \\
\hline $\begin{array}{l}\text { Sensation } \\
\text { Seeking }\end{array}$ & $\begin{array}{l}\text { SS1 } \\
\text { SS2 } \\
\text { SS3 }\end{array}$ & $\begin{array}{l}\text { You jump into new situations without much } \\
\text { thought. } \\
\text { You quit your job without finding another } \\
\text { one. } \\
\text { You are willing to take a risk in order to get } \\
\text { what you want. }\end{array}$ \\
\hline $\begin{array}{l}\text { Conformity } \\
\text { tendency }\end{array}$ & $\begin{array}{l}\text { Ct1 } \\
\text { Ct2 }\end{array}$ & $\begin{array}{l}\text { Your friend crosses the road like the } \\
\text { crossing type that you have selected in a } \\
\text { question 1, when you prompt him/her to do } \\
\text { it. } \\
\text { You cross the road like the crossing type that } \\
\text { you have selected in a question 1, when } \\
\text { your friend prompts you to do it. }\end{array}$ \\
\hline
\end{tabular}

\section{Model estimation and results}

\subsection{Normality check}

In order to adopt the Maximum Likelihood estimation method to build the CFA and SEM, we first checked if the data follow (or do not severely violate) a normal distribution. So, in general terms, the absolute values of kurtosis indexes larger than 10 and the absolute values of skew indexes larger than 3 are indication that there is severe violation of normality (Kline, 2015). In this study, Table 4 which represent the normality check for first sample relate to Dalian city that the skew indexes range from -1.824 to -0.234 , the kurtosis indexes range from 1.625 to 5.735 for Dalian city. Similarly, for Djibouti city, the skewness indexes and kurtosis indexes range from -2.821 to -0.653 and 5.689 to 1.008 , respectively. Thus, we can see in Tables 4 and 5 that there is no extreme violation of normality and Maximum Likelihood could be adopted.

Table 4. Kurtosis and Skewness indexes for Djibouti city

\begin{tabular}{|c|c|c|c|}
\hline Constructs & Indicators & Kurtosis & Skewness \\
\hline \multirow{6}{*}{ Attitude } & Att1 & 4.932 & -2.821 \\
\hline & Att2 & 3.725 & -2.083 \\
\hline & Att3 & 1.843 & -0.973 \\
\hline & Att4 & 1.655 & -0.853 \\
\hline & Att5 & 1.732 & -0.794 \\
\hline & Att6 & 1.543 & -0.653 \\
\hline \multirow{4}{*}{ Subjective Norm } & SN1 & 5.689 & -1.942 \\
\hline & SN2 & 2.154 & -1.625 \\
\hline & SN3 & 2.463 & -1.268 \\
\hline & SN4 & 1.689 & -1.873 \\
\hline \multirow{4}{*}{$\begin{array}{l}\text { Perceived Behavioral } \\
\text { Control }\end{array}$} & PBC1 & 2.671 & -1.823 \\
\hline & PBC2 & 3.472 & -2.783 \\
\hline & PBC3 & 2.768 & -1.578 \\
\hline & PBC4 & 1.008 & -0.978 \\
\hline \multirow{3}{*}{ Behavioral intention } & $\mathrm{Bl}$ & 3.291 & -1.456 \\
\hline & $\mathrm{BI} 2$ & 2.329 & -1.501 \\
\hline & $\mathrm{B} / 3$ & 1.932 & -0.843 \\
\hline \multirow{3}{*}{ Sensation Seeking } & SS1 & 5.087 & -2.571 \\
\hline & SS2 & 2.941 & -0.908 \\
\hline & SS3 & 3.541 & -1.848 \\
\hline \multirow{2}{*}{ Conformity tendency } & Ct1 & 4.687 & -2.214 \\
\hline & $\mathrm{Ct} 2$ & 2.876 & -1.904 \\
\hline
\end{tabular}

\subsection{Measurement model}

First of all, the properties of the measurement model were assessed by checking the convergent validity, reliability, and discriminant validity. The value of composite reliability (CR) for all variables (see Tables 6 and 7 ) was higher than 0.6 for both cities (Dalian city and Djibouti city), thereby proving the reliability of the model (Bagozzi \& Yi, 1988). Tables 5 and 6 show that the factor loadings of all items were higher than 0.5 , and also we checked the values of average variance extracted (AVE) for all constructs which were also higher than 0.5 , proving the convergent validity of the model (Fornell \& Larcker, 1981). We also evaluated the square root of AVE for each construct of the model (diagonal values) in Tables 7 and 8 and found that they were higher than the inter- 
construct correlations (off-diagonal values), showing discriminant validity for the model (Chin, 2014). Thus, the measurement models meet the requirement for the reliability and validity of the constructs for both cities.

Several goodness-of-fit indices are used in order to evaluate how well the measurement model represents the sample. The $p$-value of the Chi-square for Dalian data was $0.000(x 2=454,567, d f=162)$ and for Djibouti data, it was $0.000\left(X^{2}=478,392, \mathrm{df}=156\right)$. As role of thumb, the $p$-value must be larger than 0.05 for good model fit. However, the Chi-square is too sensitive to large sample size and usually rejects the model when the sample is large (Bentler \& Bonett, 2014). One way to overcome the issue of effect of sample size is to use the use of the normed Chi-square (X2/df) (Wheaton et al., 2014). (Wheaton et al., 2014) suggested a normed Chi-square between 1 and 5 for an acceptable fit. The value obtained for two samples in this study were $\mathrm{x} 2 / \mathrm{df}=2.80, \mathrm{x} 2 / \mathrm{df}=$ 3.06 , showing an acceptable fit. Others indices were also used such as the Root Mean Square Error of Approximation (RMSEA), Standardized Root Mean Square Residual (SRMR), The Comparative Fit Index (CFI), Normed-Fit Index (NFI) and Tucker-Lewis Index (TLI) . To indicate a good fit, the value of CFI, NFI and TLI should be equal or higher than 0.95, the RMSEA less than 0.06 and SRMR less than 0.08 (Hu \& Bentler, n.d.; Kline, 2015). All relevant fit indexes of the measurement model in Tables 6 and 7 ( $\mathrm{X} 2 / \mathrm{df}=2.80$; $\mathrm{CFI}=0.978$, TLI $=0.982, \mathrm{RMSEA}=0.036, \mathrm{SRMR}=0.062$ for Dalian city and $\mathrm{X} 2 / \mathrm{df}=3.06, \mathrm{CFI}=0.964, \mathrm{TLI}=0.976$, RMSEA $=$ 0.041 , SRMR $=0.058$ for Djibouti City) were within the recommended ranges; demonstrating that the measurement model fulfilled all criteria for model fit.

Table 5.Validity and reliability of the measurement model (Dalian city).

\begin{tabular}{|c|c|c|c|c|c|}
\hline Constructs & Items & $\begin{array}{l}\text { Factors } \\
\text { loading }\end{array}$ & AVE & $\begin{array}{l}\text { Cronbach's } \\
\text { Alpha }\end{array}$ & CR \\
\hline Attitude & $\begin{array}{l}\text { Att1 } \\
\text { Att2 } \\
\text { Att3 } \\
\text { Att4 } \\
\text { Att5 } \\
\text { Att6 }\end{array}$ & $\begin{array}{l}0.888 \\
0.682 \\
0.751 \\
0.774 \\
0.889 \\
0.743\end{array}$ & 0.626 & 0.894 & 0.908 \\
\hline $\begin{array}{l}\text { Subjective } \\
\text { Norm }\end{array}$ & $\begin{array}{l}\text { SN1 } \\
\text { SN2 } \\
\text { SN3 } \\
\text { SN4 }\end{array}$ & $\begin{array}{l}0.817 \\
0.811 \\
0.713 \\
0.857\end{array}$ & 0.642 & 0.867 & 0.887 \\
\hline $\begin{array}{l}\text { Perceived } \\
\text { Behavioral } \\
\text { Control }\end{array}$ & $\begin{array}{l}\text { PBC1 } \\
\text { PBC2 } \\
\text { PBC3 } \\
\text { PBC4 } \\
\end{array}$ & $\begin{array}{l}0.835 \\
0.845 \\
0.763 \\
0.844 \\
\end{array}$ & 0.676 & 0.878 & 0.893 \\
\hline $\begin{array}{l}\text { Behavioral } \\
\text { intention }\end{array}$ & $\begin{array}{l}\mathrm{B} 11 \\
\mathrm{~B} 12 \\
\mathrm{~B} 13\end{array}$ & $\begin{array}{l}0.74 \\
0.897 \\
0.865\end{array}$ & 0.7 & 0.912 & 0.874 \\
\hline $\begin{array}{l}\text { Sensation } \\
\text { Seeking }\end{array}$ & $\begin{array}{l}\text { SS1 } \\
\text { SS2 } \\
\text { SS3 }\end{array}$ & $\begin{array}{l}0.785 \\
0.953 \\
0.834\end{array}$ & 0.739 & 0.894 & 0.884 \\
\hline $\begin{array}{l}\text { Conformity } \\
\text { tendency }\end{array}$ & $\begin{array}{l}\mathrm{Ct} 1 \\
\mathrm{Ct} 2\end{array}$ & $\begin{array}{l}0.953 \\
0.835\end{array}$ & 0.802 & 0.892 & 0.89 \\
\hline
\end{tabular}
root of AVE in diagonals) (Djibouti city).

\begin{tabular}{|l|l|l|l|l|l|l|}
\hline & ATT & SN & PBC & BI & SS & CT \\
\hline ATT & 0.774 & & & & & \\
\hline SN & $0.365^{* *}$ & 0.787 & & & & \\
\hline PBC & $0.634^{* *}$ & $0.221^{* *}$ & 0.796 & & & \\
\hline BI & $0.498^{* *}$ & $0.365^{* *}$ & $0.651^{* *}$ & 0.818 & & \\
\hline SS & $0.176^{* *}$ & $0.434^{*}$ & $0.642^{* *}$ & $0.547^{* *}$ & 0.827 & \\
\hline CT & $0.763^{* *}$ & $0.452^{* *}$ & $0.411^{* *}$ & $0.111^{* *}$ & $0.375^{* *}$ & 0.856 \\
\hline
\end{tabular}

Note: * Significant at the 0.05 level (two-tailed); ${ }^{* *}$ Significant at the 0.01 level (two-tailed). 


\subsection{Path analysis}

Tables 9 and 10 display the results of the path analyses with standardized coefficients. Similar to the measurement model, the structural equation modeling results showed that the model fits the data for both cities $(\mathrm{X} 2 / \mathrm{df}=315.306, \mathrm{df}=67, \mathrm{p}<0.001 ; \mathrm{X} 2 / \mathrm{df}=4.7 ; \mathrm{CFI}=$ $0.956 ; \mathrm{TLI}=0.981 ; \mathrm{RMSEA}=0.043 ; \mathrm{SRMR}=0.073$, ; $(\mathrm{X} 2=438.033, \mathrm{df}=104, \mathrm{p}<0.001 ; \mathrm{X} 2 / \mathrm{df}=4.21 ; \mathrm{CFI}=$ $0.963 ; \mathrm{TLI}=0.974 ; \mathrm{RMSEA}=0.029 ; \mathrm{SRMR}=0.063$ ).

Attitude (ATT) positively affected the behavioral intention $(\mathrm{BI})$ when Pedestrian are crossing the road in unsafely way for both cities $(\beta=0.162, p<0.05$ and $\beta$ $=0.148, p<0.05$ for Dalian and Djibouti, respectively), providing support for $\mathrm{H} 1$. The effect of subjective norm (SN) on BI was also significant and positive $(\beta=0.581$, $p<0.05$ and $\beta=0.674, p<0.05$, for Dalian and Djibouti, respectively), supporting $\mathrm{H} 2$

Table 9.Structural equation modeling (SEM) results (Dalian city)

\begin{tabular}{|l|l|l|l|l|l|}
\hline Hypotheses & Path & Coeff. & SE & $\begin{array}{l}\text { V- } \\
\text { Value }\end{array}$ & Results \\
\hline H1 & ATT $\rightarrow \mathrm{BI}$ & 0.162 & 0.109 & 0.004 & Supported \\
\hline H2 & SN $\rightarrow \mathrm{BI}$ & 0.581 & 0.018 & 0.037 & Supported \\
\hline H3 & PBC $\rightarrow \mathrm{BI}$ & 0.743 & 0.262 & 0.843 & Unsupported \\
\hline H4 & SS $\rightarrow \mathrm{BI}$ & 0.209 & 0.068 & 0.902 & Unsupported \\
\hline H5 & CT $\rightarrow \mathrm{BI}$ & 0.464 & 0.079 & 0.009 & Supported \\
\hline
\end{tabular}

Note: Model measurement fits: $\chi^{2}=315.306, d f=67, p<0.001 ; \chi 2 / d f=4.7 ; C F I=$ $0.956 ; T L I=0.981 ; R M S E A=0.043 ;$ SRMR $=0.073$, AVE $=$ average variance extracted, $C R=$ composite reliability.

Table 10.Structural equation modeling (SEM) results (Djibouti City)

\begin{tabular}{|l|l|l|l|l|l|}
\hline Hypotheses & Path & Coeff. & SE & p-Value & Results \\
\hline H1 & ATT $\rightarrow \mathrm{BI}$ & 0.148 & 0.002 & 0.006 & Supported \\
\hline H2 & SN $\rightarrow \mathrm{BI}$ & 0.674 & 0.019 & 0.013 & Supported \\
\hline H3 & PBC $\rightarrow \mathrm{BI}$ & 0.111 & 0.005 & 0.022 & Supported \\
\hline H4 & SS $\rightarrow \mathrm{BI}$ & 0.352 & 0.29 & 0.001 & Supported \\
\hline H5 & CT $\rightarrow \mathrm{BI}$ & 0.797 & 0.045 & 0.015 & Supported \\
\hline
\end{tabular}

Note: Model measurement fits: $X^{2}=438.033, d f=104, p<0.001 ; \quad X^{2} / d f=4.21$; $\mathrm{CFI}=0.963 ; \mathrm{TLI}=0.974 ; \mathrm{RMSEA}=0.029 ; \mathrm{SRMR}=0.063, \mathrm{AVE}=$ average variance extracted, $C R=$ composite reliability.

Perceived Behavioral Control (PBC) and Sensation Seeking (SS) did not show any impact on BI in Dalian City $(\beta=0.743, p>0.05$ and $\beta=0.209, p>0.05$, respectively). So, $\mathrm{H} 3$ and $\mathrm{H} 4$ are not confirmed for Dalian City. However, for Djibouti, PBC and SS both had significant positive effect on $\mathrm{BI}(\beta=0.111, \mathrm{p}<0.05$ and $\beta=0.352, p<0.05$, respectively), providing support for $\mathrm{H} 3$ and H4. Conformity tendency (CT) had a significant and positive impact on behavioral intention (BI) for both cities $(\beta=0.464, p<0.05$ and $\beta=0.797, p$ $<0.05$ for Dalian City and Djibouti City, respectively), providing support for $\mathrm{H} 5$. Altogether, our analysis model explained $60 \%$ of the variance in the behavioral intention for Djibouti City and $50 \%$ of the variance in the behavioral intention for Dalian City.

\section{Conclusions and future research}

\subsection{Conclusions}

This paper examined pedestrians' intentions to violate traffic rules when crossing the road using the Theory of Planned Behavior coupled with other constructs (sensation seeking and conformity tendency). The data was collected in Dalian City (China) and Djibouti City (Djibouti). The major findings are summarized below.

The results show that the basic components of TPB have significant effect on the intention for both cities except for PBC, which is insignificant in Dalian city. This indicates that the basic components of TPB are important predictors of the intention to violate traffic rules, making the TPB an appropriate tool for understanding pedestrian crossing behavior. In addition the results from Dalian city prove the earlier researchers' conclusion that PBC may have a weaker relationship with intention than attitude and the subjective norm $(H$. Zhou et al., 2016).

Interestingly, conformity tendency showed a high amount of variance in behavioral intention for both cities (Dalian city and Djibouti city), indicating that this construct is one of the most important factors which influenced the pedestrians' intention. This finding supports previous studies (H. Zhou et al., 2016; R. Zhou, Horrey, et al., 2009) and means that people would be more likely to violate traffic rules (e.g. crossing against a traffic light) when others are doing. So, this finding also indicates that the variable of conformity, defined as an individual's readiness (or intention) to be influenced by others varies from the measure of subjective norms. The current study also found that sensation seeking significantly affected pedestrian's crossing intention in Djibouti city, but its effect was insignificant in Dalian city. The sensation seekers would be expected to engage in risky activities such as the violation of traffic rules. The peoples of Djibouti violate the traffic rules. They are not aware about traffic rules. The traffic signals are newly installed in Djibouti and the peoples have no awareness about the traffic signals, so most of the peoples are ignoring the traffic signals but in Dalian the peoples are followed the traffic rules and they are aware about traffic signals.

The findings have implications not only for scholars, but also for practitioners. The results show that conformity tendency and sensation seeking are strong significant predictors of intention. Therefore, future studies should also consider these factors when investigating pedestrian crossing behavior. According to the results, the road infrastructure should be fitting to the pedestrians' characteristics. For example, integrate a specific place (walking place) like building a bridge over the road in order to decrease the probability of an unlawful crossing. Similarly, the red-light duration should be compatible with the pedestrians' optimal walking duration to avoid illegal crossing. 
In summary, the present research contributes to our understanding of pedestrians' intention to violate traffic rules when crossing the road by using an extended TPB. Overall, the current paper proves that the TPB is an appropriate theoretical model for understanding pedestrians' intention regarding the violation of traffic rules. The second contribution of this paper is its identification of sensation seeking and conformity tendency as significant predictors of behavioral intention. Furthermore, to the best of our knowledge, the current research was the first attempt to explore pedestrian behavior in Africa (Djibouti city) using psychological factors in the examined model. Therefore, the present study has provided the insight into pedestrian violating behavior when crossing the road in African countries.

\subsection{Future research}

The current study has some limitations. First the use of intention only in TPB, does not allow an assessment of actual behavior. Extension from behavioral intention to actual behavior should be tested. However, our intention was not to predict risk behaviors or measure increments in actual risk, but rather to provide a theoretical structure to the examination of a real problem affecting pedestrians, especially in developing countries. Another limitation of this study can be the small number of items. In order to keep high internal reliability of the data, a small number of items were included in the final questionnaire, which could affect the results. In the future studies, it would be desirable to increase the number of items in each construct.

\section{References}

[1] Ã, D. S. D., \& Hausenblas, H. A. (2005). Elicitation studies and the theory of planned behavior: A systematic review of exercise beliefs. 6 , $1-31$. https://doi.org/10.1016/j.psychsport.2003.08.001

[2] AJZEN, I. (1991). The Theory of Planned Behavior. 211, 179211.

[3] Ajzen, I. (2014). Intention, Perceived Control , and Weight Loss: An Application of the Theory of Planned Behavior. June. https://doi.org/10.1037//0022-3514.49.3.843

[4] Albarracín, D. (2001). Theories of Reasoned Action and Planned Behavior as Models of Condom Use: A Meta- Analysis.

[5] Bagozzi, R. P., \& Yi, Y. (1988). On the evaluation of structural equation models. Journal of the Academy of Marketing Science, 16(1), 74-94. https://doi.org/10.1007/BF02723327

[6] Behavior, S. (1995). Basic temperament components of loneliness, shyness, and conformity a. 23(3), 253-263. https://doi.org/10.2224/sbp.1995.23.3.253

[7] Ben-ari, O. T., \& Shay, E. (2012). The association between risky driver and pedestrian behaviors: The case of Ultra-Orthodox Jewish road users. Transportation Research Part F: Psychology and Behaviour, 15(2), 188-195. https://doi.org/10.1016/j.trf.2011.12.005

[8] Bentler, P. M., \& Bonett, D. G. (2014). Significance Tests and Goodness-of-Fit in Analysis of Covariance Structures Significance Tests and Goodness of Fit in the Analysis of Covariance Structures. August. https://doi.org/10.1037/00332909.88.3.588

[9] Boyle, C. A. O. (n.d.). Understanding adherence to hand hygiene recommendations: The theory of planned behavior. 352-360. https://doi.org/10.1067/mic.2001.118405

[10] Brijs, K., Daniels, S., Brijs, T., \& Wets, G. (2011). An experimental approach towards the evaluation of a seat belt campaign with an inside view on the psychology behind seat belt use. Transportation Research Part F: Psychology and Behaviour, 14(6), 600-613. https://doi.org/10.1016/j.trf.2011.07.003

[11] Chin, W. W. (2014). The Partial Least Squares Approach to Structural Equation Modeling. April.

[12] Elliott, M. A., Armitage, C. J., \& Baughan, C. J. (2003). Drivers ' Compliance With Speed Limits: An Application of the Theory of $\begin{array}{lll}\text { Planned } & \text { Behavior. } & \text { 88(5), }\end{array}$ https://doi.org/10.1037/0021-9010.88.5.964

[13] Fila, S. A., \& Smith, C. (2006). Applying the Theory of Planned Behavior to healthy eating behaviors in urban Native American youth. 10, 1-10. https://doi.org/10.1186/1479-Received

[14] Fornell, C., \& Larcker, D. F. (1981). Evaluating Structural Equation Models with Unobservable Variables and Measurement. XVIII(February), 39-50.

[15] Fornell, C., Larcker, D., Perreault, W., \& Anderson, C. (1988). Structural Equation Modeling in Practice: A Review and Recommended Two-Step Approach. 103(3), 411-423.

[16] Forward, S. E. (2018). The theory of planned behaviour: The role of descriptive norms and past behaviour in the prediction of drivers' intentions to violate. Transportation Research Part F: Psychology and Behaviour, 12(3), 198-207. https://doi.org/10.1016/j.trf.2008.12.002

[17] Godin, G. (1996). The Theory of Planned Behavior: A Review of Its Applications to Health- Related Behaviors. November. https://doi.org/10.4278/0890-1171-11.2.87

[18] Guo, T., Gregg, C., Boukh-viner, T., Kyryakov, P., Goldberg, A., Bourque, S., Banu, F., Haile, S., Milijevic, S., Hung, K., San, Y., Solomon, J., Wong, V., \& Titorenko, V. I. (2007). A signal from inside the peroxisome initiates its division by promoting the remodeling of the peroxisomal membrane. 177(2), 289-303. https://doi.org/10.1083/jcb.200609072

[19] Hu, L., \& Bentler, P. M. (n.d.). Structural Equation Modeling: A Multidisciplinary Journal Cutoff criteria for fit indexes in covariance structure analysis: Conventional criteria versus new alternatives. July 2012, 37-41.

[20] Iversen, H. (2004). Risk-taking attitudes and risky driving behaviour. 7, 135-150. https://doi.org/10.1016/j.trf.2003.11.003

[21] Khan, F. M., Jawaid, M., Chotani, H., \& Luby, S. (1999). Pedestrian environment and behavior in Karachi , Pakistan. 31, 335-339.

[22] Kingdom, U. (1999). Distinguishing Perceptions of Control From Self-Efficacy: Predicting Consumption of a Low-Fat Diet Using the Theory of Planned Behavior 'CHRLSTOPHER. 72-90. 
[23] Kline, R. B. (2015). Principles and Practice of Structural Equation Modeling (p. 534).

[24] L.Blue, C. (1995). The predictive capacity of the theory of reasoned action and the theory of planned behavior in exercise behavior: An integrated literature review. Research in Nursing \& Health, 18, 105-121.

[25] Martin Fishbein Icek Ajzen. (2010). Predicting Changing and Behavior The Reasoned Action Approach (p. 509).

[26] Marvin Zuckerman. (1979). Sensation Seeking Beyond the optimal level of arousal.

[27] Marvin Zuckerman. (2006). SENSATION SEEKING AND RISKY BEHAVIOR (p. 309).

[28] Mcauley, E. (1993). Self-Efficacy and the Maintenance of Exercise Participation in Older Adults. 16(1), 103-113.

[29] Moan, I. S., \& Rise, J. (2011). Predicting intentions not to "drink and drive " using an extended version of the theory of planned behaviour. 43, 1378-1384. https://doi.org/10.1016/j.aap.2011.02.012

[30] Nemme, H. E., \& White, K. M. (2010). Texting while driving: Psychosocial influences on young people 's texting intentions and behaviour. Accident Analysis and Prevention, 42(4), 12571265. https://doi.org/10.1016/j.aap.2010.01.019

[31] Norman, P., \& Conner, M. (2006). Copyright (c) The British Psychological Society The theory of planned behaviour and binge drinking: Assessing the moderating role of past behaviour within the theory of planned behaviour Copyright (c) The British Psychological Society. 55-70. https://doi.org/10.1348/135910705X43741

[32] Qu, W., Zhang, H., Zhao, W., Zhang, K., \& Ge, Y. (2016). The effect of cognitive errors, mindfulness and personality traits on pedestrian behavior in a Chinese sample. Transportation Research Part F: Traffic Psychology and Behaviour, 41, 29-37. https://doi.org/10.1016/j.trf.2016.06.009

[33] Reynolds, B., Ortengren, A., \& Richards, J. B. (2006). Dimensions of impulsive behavior: Personality and behavioral measures Dimensions of impulsive behavior: Personality and behavioral measures. March 2018. https://doi.org/10.1016/j.paid.2005.03.024

[34] Rhodes, R. E., \& Courneya, K. S. (2003). Investigating multiple components of attitude, subjective norm , and perceived control: An examination of the theory of planned behaviour in the exercise domain. 129-146.

[35] Rosseel, Y. (2011). Lavaan: An $R$ package for structural equation modeling and more Version 0. 4-9 (BETA ). 9, 1-33.

[36] Rye, B. J. (1999). Predicting Intentions to Use Condoms: A Meta-Analysis and Comparison of the Theories of Reasoned Action and Planned Behavior'. 1624-1675.

[37] Santor, D. A., Messervey, D., \& Kusumakar, V. (2000). Measuring Peer Pressure, Popularity, and Conformity in Adolescent Boys and Girls: Predicting School Performance, Sexual Attitudes, and Substance Abuse. 29(2).

[38] Studies, C. (1996). A critical assessment of potential measurement biases in the technology acceptance model: Three experiments. 19-45.

[39] Tova Rosenbloom a, b, *, Dan Nemrodov a, Hadar Barkan a. (2004). For heaven's sake follow the rules: Pedestrians' behavior in an ultra-orthodox and a non-orthodox city. Transportation Research Part F 7 (2004) 395-404, November. https://doi.org/10.1016/j.trf.2004.10.004

[40] Traffic, P. F., Castanier, C., Deroche, T., \& Woodman, T. (2013). Theory of planned behaviour and road violations: The moderating influence of perceived behavioural control. May. https://doi.org/10.1016/j.trf.2012.12.014

[41] Vicki S. Conn, Ph. D., R. N., \& Toni Tripp-Reimer, Ph. D., R. N. ,. FAAN, and Meridean L. Maas, Ph. D. ,. R. N. ,. FAAN. (n.d.). Older Women and Exercise: Theory of Planned Behavior Beliefs. Public Health Nursing, 20(2), 153-163.

[42] Vm, F., Ra, C., Pc, M., Chemother, J. A., French, V. M., Cooper, R. A., \& Molan, P. C. (2016). The antibacterial activity of honey against coagulase-negative staphylococci. October, 228-231. https://doi.org/10.1093/jac/dki193

[43] Wheaton, B., Muthén, B., Alwin, D. F., \& Summers, G. F. (2014). ASSESSING RELIABILITY AND STABILITY. 8(May), 84-136.

[44] World Health Organisation (2013). Global status report on road safety 2013.

[45] World Health Organisation (2015). Global status report on road safety 2015.

[46] Xuehao Chu, M. G., and Michael R. Baltes, \& A. (n.d.). Why People Cross Where They Do: The Role of the Street Environment. Available to the Public through the National Technicaltnformation Service (NTIS), 5285 Port Royal Road, Springfield, VA 22161, 703-487-465, and through the NCTR Website at Http://Www.Nctr.Usl.Edu, 14-14.

[47] Zhou, H., Ballon, S., \& Qin, X. (2016). An extension of the theory of planned behavior to predict pedestrians ' violating crossing behavior using structural equation modeling. Accident Analysis and Prevention, 95, 417-424. https://doi.org/10.1016/j.aap.2015.09.009

[48] Zhou, R., \& Horrey, W. J. (2010). Predicting adolescent pedestrians ' behavioral intentions to follow the masses in risky crossing situations. Transportation Research Part F: Psychology and Behaviour, 13(3), 153-163. https://doi.org/10.1016/j.trf.2009.12.001

[49] Zhou, R., Horrey, W. J., \& Yu, R. (2009). The effect of conformity tendency on pedestrians ' road-crossing intentions in China: An application of the theory of planned behavior. 41, 491-497. https://doi.org/10.1016/j.aap.2009.01.007

[50] Zhou, R., Wu, C., Rau, P. P., \& Zhang, W. (2009). Young driving learners ' intention to use a handheld or hands-free mobile phone when driving. Transportation Research Part F: Psychology and Behaviour, 12(3), 208-217. https://doi.org/10.1016/j.trf.2008.11.003

[51] Zhuang, X., \& Wu, C. (2011). Pedestrians ' crossing behaviors and safety at unmarked roadway in China. Accident Analysis and Prevention, 43(6), 1927-1936. https://doi.org/10.1016/j.aap.2011.05.005

[52] Zuckerman, M. (2015). Sensation Seeking: Behavioral Expressions and Biosocial Bases. In International Encyclopedia of Social \& Behavioral Sciences (Second Edi, Vol. 21, p. 614). Elsevier. https://doi.org/10.1016/B978-0-08-097086-8.25036-8 